\title{
Druhá světová válka a problematika uprchlictví se zaměřením na českobudějovickou diecézi ve světle archivních materiálů biskupského archivu
} Martin Weis

\section{Úvodem}

Tváří v tvář současné uprchlické krizi, které je kontinent Evropy vystaven, se častokráte uvádí, že se jedná o největší uprchlickou krizi od konce druhé světové války. O samotné druhé světové válce v souvislosti s vyháněním obyvatel a uprchlictvím bylo sepsáno již velké množství monografií a vědeckých studií; lze nalézt velké množství rozličných statistických dat apod. V této studii proto hodláme připomenout problematiku uprchlictví spojenou s tímto tragickým úsekem lidských dějin ze specifického úhlu pohledu. Pohlédneme na uprchlictví jako na součást dějin českobudějovické diecéze let 1938 až 1947, a to zejména ve světle archivních materiálů biskupského archivu. $\mathrm{Na}$ autentických dokumentech si přiblížíme, jak žhavou otázku uprchlictví vnímal a často i sám jako uprchlík prožíval tehdejší katolický duchovní.

\section{K problematice literatury a pramenů}

K problematice uprchlictví let 1938-1947 se zaměřením na českobudějovickou diecézi bylo publikováno jen několik monografií a studií, které se našeho tématu dotýkají pouze okrajově či úzkým dílčím způsobem. ${ }^{1}$ Nejcennější zdroj informací k námi zkoumané problematice proto při-

1 České církevní dějiny z období let 1938 až 1947 obsahuje kupř́kladu monografie Jaroslav POLC, Stručnýpřehled dějin českých a moravských diecézí po třicetileté válce, Praha: KTF UK, 1995. Problematikou vyhnání českých kněží z jejich působišst nacistickým režimem a jejich následnou perzekucí se zaobírá např́klad monografie Josef BENEŠ, Kaine, kde je tvůj bratr, Praha: ČKCH, 1971; osudy sudetských německých kněží připomíná monografie Emil VALASEK, Der Kampfgegen die Priester im Sudetenland 1938 bis 1945. Eine Dokumentation, Königstein: Institut für Kirchengeschichte von Böhmen - Mähren - Schlesien, 2003. Nutno také zmínit i monografii, ve které jsou zachyceny osudy sudetských katolíků kněží i laiků ve střetu s nacistickým režimem: Rudolf GRULICH, Sudetoněmečtí katolíci jako oběti nacismu, Praha: HTF UK, 2002. K všeobecněji laděné problematice soužití Čechů a Němců lze doporučit např́íklad monografii Josef ŠKRÁBEK, Včerejší strach. Jaké to bylo mezi Čechy a Němci?, Praha: Vyšehrad, 2002; či monografii Milan SLÁDEK, Němci v Čechách, Praha: Pragma, 2002. Problematiky tzv. divokých odsunů v roce 1945 se zaměřením na jihočeský region se týká kupř́kladu monografie Josef MLYNÁRIK, Tragédie Vitorazska 1945-1953. Poprava v Tušti, Třeboň: Carpio, 2005. Dílčím způsobem se problematiky dotýkají i studie uveřejněné v časopise Archiv für Kirchengeschichte von Böhmen - Mähren - Schlesien, a to v sedmém svazku, který byl vydán v roce 1985 pod názvem Festschrift zur zweiten Säkularfeier des Bistum Budweis in Böhmen 1785-1985. Zde je nutné zmínit zejména studie Rudolf PALECZEK, Die deutschen Budweiser Diözesanen nach 1945; a Rudolf PALECZEK, Die kirchliche Administration des deutschen Anteils der Diözese Budweis 1938-1946. Taktéž upozorněme na studie Martin WEIS, Der Weg von der Diktatur des Nationalsozialismus zu den Dekreten des Präsidenten Benesch. Ein Blick in die Geschichte der katholischen Kirche in Südböhmen, HLK - Neue Folge 91/2007, s. 439-450; Martin WEIS, Hohenfurther Stift in den Jahren 1945-1948, HLK - Neue Folge 92/2008, s. 35-42; Martin WEIS, Proměny soužití českého a německého obyvatelstva na Šumavě v letech 1898-1938. Sonda do kaž- 
náší biskupský archiv, který je deponován ve Státním oblastním archivu v Třeboni. ${ }^{2}$ Nebyly opomenuty ani tištěné archivní materiály jako diecézní katalog, ${ }^{3}$ úř̌ední věstníky ${ }^{4}$ či příležitostné pokyny státní správy.

\section{Uprchlictví v důisledlku Mnichovské smlouvy a odtržení pohraničí v roce 1938}

Je nutné zdůraznit, že proudy uprchlíků směřovaly do Československa o mnoho let dříve než v roce 1938. První velká uprchlická vlna byla způsobena terorem bolševického režimu v Rusku. Když uprchlíkům pobývajícím v táborech na území Balkánu po definitivní porážce bílých vojsk a jejich spojenců začalo být zřejmé, že do své vlasti se již nebudou moci vrátit, hledali země, kde by se mohli dlouhodobě usadit a kde by nalezli uplatnění. Jednou ze zemí, která této uprchlické vlně otevřela náruč dokořán, byla i Československá republika. Ta v rámci takzvané „Ruské pomocné akce“ dle rozhodnutí z 28. července 1921 vytvořila v Československu pod patronátem ministerstva zahraničí státem organizovanou a ze státního rozpočtu financovanou pomoc ruským uprchlíkům. V období mezi první a druhou světovou válkou se tak v naší vlasti usadila velmi početná skupina uprchlíků $\mathrm{z}$ Ruska, která zde nalezla útočiště především díky iniciativám tehdejšího prezidenta T. G. Masaryka. Historici uvádí, že na podporu uprchlíků z Ruska Československo utratilo údajně víc než všechny evropské státy dohromady - hovoří se o částce téměř půl miliardy československých korun. Jistě se nejednalo jen o čirý altruismus motivovaný rusofilstvím tehdejš́ho prezidenta Masaryka, který velmi obdivoval ruskou kulturu a duchovní život předválečného Ruska. Uprchlíci z Ruska, zejména inteligence, se měli samozřejmě jaksi „na oplátku“ zapojit do průmyslového a vědeckého rozvoje mladé Československé republiky. Udává se, že řada špičkových ruských odborníků začala i přednášet na našich vysokých školách, působit v redakcích časopisů jako velice kvalitní žurnalisté apod. ${ }^{5}$

Další vlnu uprchlíků do Československa vyvolal nástup nacionálního socialismu Adolfa Hitlera $\mathrm{k}$ moci v Německu. Jednalo se o německé a později i o rakouské obyvatele, a to zejména o levicově orientované obyvatele, členy komunistické strany či sociální demokracie a též o židovské uprchlíky. Ti ale v Československu nenacházeli vesměs trvalý azyl, nýbrž byli nuceni hledat si cestu $\mathrm{k}$ další emigraci. ${ }^{6}$

V roce 1938 dochází k radikální změně poměrů ve střední Evropě. Dne 11. března 1938 se v Rakousku uskutečnil politický převrat a den poté, na žádost místních př́znivců Adolfa Hitlera, dochází ke vstupu německých vojsk na území Rakouska. Adolf Hitler pak připojuje země Rakouska k Německé říši, což formálně potvrdil i lidový plebiscit konaný 10. dubna 1939.7 Perzekuce levi-

dodennosti farních společenství ve světle materiálů biskupského archivu, Auspicia 2/2007, s. 31-36; a Martin WEIS, Osudy katolické církve na jihu Čech v období Protektorátu Čechy a Morava, Studia theologica 1/1999, s. 63-70.

2 Státní oblastní archiv v Třeboni (dále SOA Třeboň), fond Biskupský archiv (dále BA), léta 1938-1947. Jedná se zejména o archiválie ze složek označených jako spisovna 1903-1945 a perzekuce za války.

3 Catalogus saecularis et regularis cleri dioeceseos Bohemo-Budvicensis, 1938, 1939, 1940 a 1948.

4 Acta curiae episcopalis Bohemo-Budvicensis (dále ACEB) z let 1938-1947.

5 Uvádí se, že těchto uprchlíků bylo v letech 1922-1928 více než 25 000. Srov. Anastasie KOPŘIVOVÁ, Osudy ruské emigrace v Československu, Pamět' a dějiny 2/2015, s. 27-50. Dále je možné k dané problematice konzultovat pojednání Ljubov BĚLOŠEVSKÁ (ed.), Kronika kulturního, vědeckého a společenského života ruské emigrace v Československu I, 1919-1929, Praha: Slovanský ústav AV ČR, 2000; či Světlana TEJCHMANOVÁ, Rusko v Československu: Bílá emigrace v ČSR 1917-1939, Praha Jinočany: H \& H, 1993.

$6 \mathrm{~K}$ tomuto tématu lze doporučit velmi zasvěcenou monografii Kateřina ČAPKOVÁ - Michal FRANKL, Nejisté útočiště. Československo a uprchlíci před nacismem 1933-1938, Praha - Litomyšl: Paseka, 2008.

7 K tomuto tématu viz podrobněji kupř́kladu Heinz ARNBERGER (ed.), „Anschluß“ 1938. Eine Dokumentation, Wien: Österreichischer Bundesverlag, 1988; nebo novější publikaci Werner WELZIG, Anschluss: März-April 1938 in Österreich, Wien: Verlag der Öster- 
cově smýšlejících obyvatel, osob židovské národnosti, ale i angažovaných křestanů se začíná i zde realizovat dle německého nacistického vzoru. ${ }^{8}$

Další obětí rozpínavého německého nacismu se mělo záhy na to stát na podzim roku 1938 Československo. Celkovou napjatou politickou situaci nám dobře dokumentují dvě zprávy z úředního věstníku biskupské konsistoře. První je velmi důrazná výzva z 29. září 1938, ve které se duchovním správcům nařizovalo, aby z kazatelen i jinak používali každé prŕležitosti a vybízeli své farníky ke klidu, rozvaze, modlitbám za vlast a důvěře k vládě Československé republiky.9 Druhým pokynem, který již prakticky připravuje duchovní římskokatolické církve na eventuální nutnost evakuace území zasaženého válečným konfliktem, jsou pokyny pro zabezpečení matrik, odvoz drahocennějších bohoslužebných předmětů a vzácných uměleckých památek do vnitrozemí či jejich zakopání na utajeném místě. ${ }^{10}$

Politická krize v mezinárodních vztazích vyvrcholila 30. září 1938 uzavřením tzv. Mnichovské dohody. $\mathrm{V}$ jejím důsledku došlo $\mathrm{k}$ postoupení téměř jedné třetiny území českých zemí Německu. Ve dnech 1. až 10. října 1938 obsadila německá vojska naše pohraničí, přričemž jihozápadní Čechy byly přičleněny k Bavorsku a jižní Čechy k rakouské župě Horní Dunaj. Českobudějovický biskup Šimon Bárta reagoval na vzniklou situaci pastýřským listem, ve kterém již v samém úvodu vzpomíná trpkého údělu uprchlíků: „Velká pohroma vlasti a národa, hluboký žal a zármutek, který proto srdce nás všech svírá, trpký úděl statisíců našich bratří a sester a teskné obavy o budoucnost našeho národa nutkají vašeho arcipastýře a otce, aby k Vám promluvil otcovské slovo“; a důrazně vybízí věřící diecéze k solidaritě s uprchlíky z našeho pohraničí: „mezi nejbližšími úkoly a naléhavou povinností je péče o naše bližní, kteří v posledních dnech utrpěli těžké existenční škody ztrátou majetku, zaměstnání a domova". ${ }^{11} \mathrm{~V}$ obdobném duchu hovořil i společný pastýřský list podepsaný pražským arcibiskupem kardinálem Kašparem, olomouckým arcibiskupem Prečanem, českobudějovickým biskupem Bártou, brněnským biskupem Kupkou, královéhradeckým biskupem Píchou a litoměřickým biskupem Weberem. I zde se krom slov útěchy a povzbuzení nalézá výzva našich ordinářủ k obětavé práci a uskrovnění ku pomoci strádajícím bližním, a to připomenutím slov Písma: „Kdo má statek tohoto světa a vidí bratra svého, an trpí nouzí, a zavře před ním srdce své, kterak láska Boží zůstává v něm? Dítky, nemilujme slovem, ani jazykem, nýbrž skutkem a v pravdě, praví hlasatel lásky sv. Jan. Tím projevíte i své opravdové vlastenectví." ${ }^{2}$

Mnozí katoličtí duchovní českobudějovické diecéze začali řešit velmi důležitou existenční i morální otázku, zda se přidat k proudu uprchlíků a opustit svěřenou farnost, či zůstat a vystavit se nebezpečí pronásledování a perzekuce. Toto dilema nám dobře dokumentuje následující dopis

reichischen Akademie der Wissenschaften, 2010. V češtině je možné konzultovat př́íslušné pojednání v monografii Václav VEBER, Dějiny Rakouska, Praha: Nakladatelství Lidové noviny, 2002, s. 531-548.

8 Nacistická církevní politika probíhala v několika fázích. První fáze, která trvala přibližně do roku 1935, se vyznačovala hledáním cesty k pokojnému soužití. Z téhož období je také konkordát uzavřený mezi Svatým stolcem a Německem. Nacistický režim konkordát přivítal především ze zahraničně-politických důvodů, hodlal prohloubit spolupráci s tradičně katolickými zeměmi, jako byla Itálie, Španělsko a Portugalsko. Z taktických důvodů nacisté v této první fázi své církevní politiky proti křestanským církvím nevystupovali otevřeně, přesto se snažili skrytě o jejich postupnou izolaci a vyřazení ze společnosti. Druhá fáze církevní politiky nacistického Německa probíhala v letech 1936-1940 a vyznačovala se již neskrývanou snahou o podřízení všech církví totalitnímu režimu, a to i za pomoci represí. Na tuto vzniklou situaci reagoval papež Pius XI. encyklikou Mit brennender Sorge, ve které hájil křestanství vůči nacistickému novopohanství. Srov. František VAŠEK - Zdeněk ŠTĚPÁNEK, Trnitá cesta moravského duchovenstva (1939-1945), Brno: Šimon Ryšavý, 2003, s. 17n.

9 Srov. ACEB 1938, č. 9, s. 53.

10 Srov. tamtéž, s. 54, Pokyny pro př́ípad evakuace území.

11 ACEB 1938, č. 10, př́loha pastýřský list datovaný 23. 10. 1938.

12 ACEB 1938, č. 11, př́loha pastýřský list datovaný 2. 10. 1938. 
katolického duchovního z farnosti v Německém Rychnově u Frymburka: „Poněvadž jsou doby vážné a nelze předvídat budoucnost, prosím o laskavou odpověd', směl-li bych opustiti svěřenou osadu v př́ípadě, kdyby, nedej Pán Bůh, mělo v budoucnosti dojít ku srážce mezi naším a německým státem. Celá osada táhne se podél hranic, a pokud jest mi známo, $\mathrm{v}$ př́ípadě srážky bylo by obyvatelstvo vyzváno, aby opustilo území, v první řadě státní zaměstnanci. $V$ tomto př́ípadě by asi zdejší kraj až po Vltavu byl obětován k získání času transportu našeho vojska a vícero budov by bylo před ústupem zničeno. Kdyby pak jednou toto území mělo připadnout $\mathrm{k}$ Německu, ač poslední události nasvědčují tomu, že k podobnému nedojde, prosím, aby v případě tom sama nejdůstojněǰ̌í Konsistoř žádala o mé vydání pro Československou republiku, poněvadž bych nikdy pod hákovitým kř́ižem sloužiti nechtěl. To pro ten př́ípad, že bych sám žádati nesměl. 23. 7 . $1938 .{ }^{\text {"13 }} \mathrm{Na}$ tento úpěnlivý dotaz duchovního adresovala českobudějovická biskupská konsistoř následující odpověd zcela dle běžných norem učení katolické morálky o povinnostech duchovního správce: „K dotazu sdělujeme: nebudou-li dány zvláštní pokyny duchovním správám, platí, čemu učí morálky o povinnostech pastýřu duchovních. Setrvá-li obec věrících, musí setrvati duchovní pastýř anebo postarati se, by nezůstali bez duchovní správy. Kdyby došlo k evakuaci bud’ na rozkaz moci státní, nebo de facto, jde duchovní pastýř se svým stádcem. ${ }^{~}{ }^{14}$

Že tento dopis nebyl ojedinělý, dokládá kupř́íkladu žádost faráře z Věžovaté Pláně, co má dělat, když vesnice byla zabrána německým vojskem, a následná urgence odpovědi $s$ tím, že musí z politických a národnostních důvodů ze své farnosti odejít: „Nejdůstojnější biskupská konsistoři v Českých Budějovicích! V nejhlubší úctě podepsaný dovoluje si uctivě služebně hlásiti, že dne 8. října 1938 byla Pláně Věžovatá zabrána pro Německou říši - říšskoněmeckým vojskem. Z tohoto důvodu prosí v nejhlubší úctě podepsaný o další milostivé instrukce. $Z$ nedostatku poštovních známek přikládá na milostivou odpověd’ 5 Kč kolek doporučenou. Farní úřad v Pláni Věžovaté dne 8. října 1938 Václav Jelínek, farár. “ ${ }^{15}$ Když nedostal z Českých Budějovic odpověd, následovala urgence tohoto znění: „Nejdůstojnější biskupská konsistoři v Českých Budějovicích! Pod č. j. 308 ze dne 8. října t.r. dovolil si v nejhlubší úctě podepsaný oznámiti, že týmž dnem byla Věžovatá Pláně zabrána říšským vojskem pro Německou říši a prosil milostivé služební instrukce. Ježto žádné sdělení dosud nedošlo, dovoluje si v nejhlubší úctě podepsaný - v předpokladu, že asi první dopis nebyl doručen, uctivě oznámiti, že zde i ze zdravotních důvodů zůstati nemůže a že dle možnosti co nejdříve dovolím si přijíti. Farní úřad v Pláni Věžovaté dne 25. října 1938 Václav Jelínek. ${ }^{{ }^{116}}$

Ze stejného roku nám dokládá žádost o přeložení v důsledku úpravy státních hranic i jiný dopis nalezený v biskupském archivu: „Nejdůstojnější biskupské konsistoři v Českých Budějovicích. V úctě podepsaný prosím, aby mi byla prozatímně propůjčena nějaká česká fara ve vnitrozemí, protože dne 25. X. t.r. má zde býti plebiscit a zdejší občané prohlašují, že všichni budou hlasovat pro německou říši a že zde žádného Čecha ani českého faráře nestrpí. Jest tedy samozřejmé, že zde za takových poměrů nemohu zůstati, jinak bych byl vydán největšímu pronásledování a utrpení. Pastorace by zde byla úplně nemožná. Jsem zde již skoro 22 let a prožil jsem mnoho příkoří a udávání. Všechny doklady $\mathrm{k}$ žádosti jsou dosud u nejdůstojnější biskupské konsistoře $\mathrm{z}$ února t.r. Bukovec dne 5. X. 1938, Josef Jačka, farár.r. ${ }^{{ }^{17}}$

13 SOA Třeboň, fond BA, karton č. 958, signatura I - E - 4, spisovna 1903-1945, složka 1938, originál dopisu, signovaný.

14 SOA Třeboň, fond BA, karton č. 958, signatura I - E - 4, spisovna 1903-1945, složka 1938, koncept odpovědi ze dne 26. 7. 1938, odeslána 27. 7. 1938, originál nesignovaný.

15 Tamtéž, originál dopisu, signovaný, bez konceptu odpovědi.

16 Tamtéž, originál dopisu, signovaný, bez konceptu odpovědi.

17 Tamtéž, originál dopisu, signovaný, bez konceptu odpovědi. 
Následující dopis nám dokládá nejenom složitou uprchlickou, národnostní a politickou situaci po záboru jihočeského pohraničí, nýbrž i ojedinělé kněžské selhání duchovního německé národnosti, který se přiklonil v duchu německé nacionálně-socialistické propagandy ke „kultu hákového kříže. Jedná se o dopis Farního úřadu Lažiště ze dne 21. 12. 1938 popisující vskutku zoufalou situaci v odtržených oblastech po náboženské stránce: „Nejdůstojnější biskupská konsistoři v Českých Budějovicích! (...) Dále oznamuji, že byl mi z osady zabrán Kratusín - ale prosím nepřidělujte jej Záblatí, potud, pokud Říše dovolí Kratuským sem do kostela a mě tam zaopatřovat. Jdou všichni do kostela sem do Lažiště a já tam zaopatřuji. Již třikrát $\mathrm{v}$ záboru a vždy mě tam pustili říšské úřady. $\mathrm{V}$ den záboru ráno jsem měl mši svatou $\mathrm{v}$ kapli Kratuské a byl to nejsmutněǰ̌́ den života za hodinu potom je zabrali. A Kratuští - z nichž za sedm let ani jeden nevynechal svaté svátosti $\mathrm{v}$ postě, jsou zoufalí - protože záblatský pán se nechtěl s dětmi jejich modlit $\mathrm{v}$ české škole, vodil Henleiny a dnes má svatý křriž ozdoben z každé strany jedním (namalován hákový kříž) doma ve faře. Tak mi řekl s rukou k př́śsaze zdviženou starý Vojta, sedlák z Kratušína - a prohlásil: Pán Bůh nám musí odpustit, budeme umírat bez kněze, když budeme odkázáni na Záblatí. Není v tom osoba moje, ne. Prosil jsem je, aby odpustili a oni, že se nehněvají, ale že jsou katolíci a v Záblatí už není svatý křriž. Je tam s hákovým. Co mám dělat? České hraničářské a věrící hlavy to dokážou, protože nevidí v Záblatí svatý kř́ž sám. Prosím Vás, nežaluji, a nerad bych, aby snad Záblatský pán se zlobil víc na ně i na mě. Jen žádám, aby mi byla ponechána jurisdikce faráře potud, pokud budu moci se svolením zákonů do Kratušína a části Záblatí též zabraného. Část Chlístova to byli Němci, ti at jdou do Záblatí. Štola, která by patřila dp. faráři v Záblatí, at mu Kratuští a ostatní odvádějí. Děti do nového roku jdou sem též do školy. Prosil jsem se svým bratrem, zdejším řídícím úřadem, aby je sem nechali. Odpověd úřadů říšských byla: ano, dokud dovolí zákony. Měl jsem z Kratušína pohřeb, také sem do Lažišť - Tento týden. Úřady pustily. Už propaganda pracuje mezi Čechy katolíky. Věříme v Boha jako vy - jen nechceme židy, Krista, Marii, Josefa - to přejde. My chceme jen Boha. (...) Smutný život, vnitrozemí nemá ponětí. Stržena mládež už úplně. Ein Gott und Führer. Budou ty doby pro Sudety horší, než pro nás byla doba popřevratová. (...) V Lažišti, dne 21. 12. 1938 Josef Dušák, farár. “ ${ }^{\text {18 }}$

V odtržených oblastech diecéze bylo 139 farností, ve kterých žilo cca 258000 katolíků a 210 kněží. Velké přesuny českých duchovních do vnitrozemí, kteří se tak sami stali uprchlíky, dokumentuje již listopadové č́slo úředního věstníku diecéze $\mathrm{v}$ rubrice personálie. Na uvolněná místa byli jmenováni jako administrátoři duchovní německé národnosti, přičemž nutno podotknout, že těchto duchovních bylo méně než uprázdněných farností. Zejména chudé horské farnosti Šumavy zůstaly dlouho neobsazené. ${ }^{19} \mathrm{~V}$ prosinci 1939 byly odtržené farnosti přičleněny pod správu sousedních diecézí v německé říši. ${ }^{20}$

Po rozbití Československa a vzniku Protektorátu Čechy a Morava nacisté svou církevní politiku začali ihned uskutečňovat i na našem území, kde ji řídil úřad říšského protektora. V této souvislosti je nutné podívat se blíže na postavu zastupujícího rríšského protektora Reinharda Heydricha,

18 SOA Třeboň, fond BA, karton č. 958, signatura I - E - 4, spisovna 1903-1945, složka 1938, originál dopisu ze dne 21. 12. 1938, bez konceptu odpovědi.

19 Celkem odchází po zabrání pohraničí roku 1938 do vnitrozemí 32 českých duchovních a na jejich místa in territorio occupato bylo jmenováno 24 německých duchovních, srov. ACEB 1938, č. 12, s. 61-62. Lednové číslo úředního věstníku z roku 1939 uveřejňuje konkursní patent na 65 uprázdněných farních beneficií in territorio occupato, srov. ACEB 1939, č. 1, s. 5. Ne všichni čeští duchovní však opustili své místo. Jmenujme např́íklad neohroženého faráře v Klenčí P. Antonína Pospíšila, který po odtržení pohraničí podporoval všemi možnými způsoby český národní život ve své farnosti, tajně vyučoval náboženství česky na faře a pašoval z Protektorátu české náboženské knihy. Gestapem byl zatčen 27. ř́jna 1944 a po těžkých výsleších poslán do koncentračního tábora v Terezíně. Srov. Josef BENEŠ, Kaine, kde je tvůj bratr, Praha: ČKCH, 1971, s. 253n.

20 Srov. Catalogus saecularis et regularis cleri dioeceseos Bohemo-Budvicensis, 1940, s. 140n. 
který sehrál v koncipování církevní politiky nacistů velmi důležitou roli. Přestože byl vychován v náboženském duchu, roku 1936 vystoupil z katolické církve a ostře proti ní bojoval. Autoři knihy Trnitá cesta moravského duchovenstva uvádí velmi výstižnou charakteristiku Heydricha: „Neprátele nacismu redukoval do dvou duchovních a organizačních polí - Židy a politické duchovní. ${ }^{21}$ Za jakousi „frontovou organizaci“ mezinárodního židovstva považoval svobodné zednářství a u katolické církve obdobně vnímal řád jezuitů. Snad také právě proto již na začátku války uvažoval o tom, že jezuité budou posláni do koncentračních táborů na Východě. Po svém př́chodu do Prahy Heydrich smutně proslul mimo jiné také tím, že vypracoval plán na proniknutí oddaných nacistů do řad katolické církve. Hodlal vybrat z př́slušníků Hitlerjugend vhodné kandidáty, které chtěl dát pod falešnými jmény studovat teologii. Vážně počítal s tím, že za asi patnáct let by pak mohli obsadit vedoucí pozice v katolické církvi. Obdobně se podle jeho plánu mělo postupovat i proti ostatním křestanským církvím. Řada katolických duchovních odešla do zahraničí a zapojila se do zahraničního odboje, domácí organizovali pouti, které se změnily v protinacistické manifestace, a nesmíme opomenout ani statečná vlastenecká kázání mnohých duchovních. Odpor duchovenstva vůči nacistickému režimu přerostl v mnohých případech i do př́mého zapojení do domácího organizovaného odboje, přechovávání zbraní, ilegálních tiskovin a osob pronásledovaných režimem. Odveta nacistů byla častokráte velmi krutá a končila smrtí na popravišti či zplynováním v koncentračním táboře.

Jedním z hlavních důvodů perzekuce kněží bylo například praktikování norimberských rasových zákonů, nebở ani církevní zaměstnanci nesměli být židovského původu. Ve všech úředních listech diecéze českobudějovické $z$ let protektorátu nacházíme vždy alespoň na jednu stranu dlouhý seznam jmen, ke kterým $z$ př́slušných matrik farních úřadů musel být vypracován výpis křestní, svatební či úmrtní. Falšování těchto údajů, které měly doložit nežidovský původ tazatele, se trestalo velice přísně. Přesto se našlo dost katolických kněží, kteří s nasazením vlastního života takovéto zfalšované doklady vydávali, aby zachránili nejednoho člověka od transportu do Terezína či jiného koncentračního tábora na vyhlazování židovské rasy. Bohužel, našlo se i mezi naším národem několik jedinců, kteří se dali do služeb okupační moci coby provokatéři a informátoři. $\mathrm{Na}$ činnost takového provokatéra doplatil životem např́klad i jeden $\mathrm{z}$ kněží českobudějovické diecéze - P. František Vošta, děkan v Opařanech. Kněžské svěcení přijal v roce 1907 a nastoupil do duchovní správy jako kaplan v Žirovnici u Počátek. Poté byl administrátorem v Tannaberku a farářem v Klenčí. $V$ roce 1938 po odtržení pohraničí se stal děkanem v Opařanech na Táborsku. Zde v roce 1941 padl do nastražené léčky gestapa. Provokatérovi, kterému vystavil nepravé rodové doklady k potvrzení o nežidovském původu, ještě navíc sdělil, že za odměnu si nic nežádá, jen aby zůstal poctivým Čechem a dobrým křestanem. Kř́žová cesta P. Vošty započala 30. srpna 1941 vězněním a výslechy na táborském gestapu a vedla přes Prahu a Terezín do koncentračního tábora Dachau; datum a místo smrti P. Vošty je nejisté. Na dokladech zaslaných gestapem je jako datum úmrtí uveden 26. červen 1942 a jako př́čina smrti srdeční mrtvice. Josef Beneš uvádí, že dne 28. května 1942 byl P. Vošta zařazen do tzv. invalidního transportu, který končil v plynové komoře. Urna s popelem byla uložena na hřbitově v Dražicích téhož roku. ${ }^{22}$

Z těch kněží, kteř́ byli gestapem vyšetřováni a byli vyhnáni z místa působení, na tomto místě připomínáme postavu Tecelina Jaksche, O.Cist., opata kláštera ve Vy̌̌ším Brodu a generálního vikáře odtržených farností českobudějovické diecéze. Byl jako první kněz ze sudetské části diecéze vyšetřován gestapem. Zatčen byl 21. listopadu 1938 a přes měsíc byl vyšetřován v Linci a Čes-

21 Srov. František VAŠEK - Zdeněk ŠTĚPÁNEK, Trnitá cesta moravského duchovenstva (1939-1945), s. 17n.

22 Josef BENEŠ, Kaine, kde je tvůj bratr?, s. 74-78. 
kém Krumlově. Po propuštění se již nemohl vrátit do svého kláštera ve Vyšším Brodě a musel žít $\mathrm{v}$ př́sné izolaci po celou dobu druhé světové války v klášteře Porta Coeli u Tišnova. V roce 1948 musel uprchnout před nastupující komunistickou totalitou do zahraničí. ${ }^{23}$

Nejenom čeští kněží českobudějovické diecéze byli pronásledováni a žalářováni nacistickým režimem. Z 210 kněží, kteří působili v odtržených pohraničních částech českobudějovické diecéze během let 1939-1945 tři zahynuli v koncentračním táboře $\mathrm{v}$ Dachau, dalších pět jich věznění v koncentračních táborech přežilo, 16 kněží muselo opustit své farnosti, protože v nich, popřípadě v celých Sudetech, dostali zákaz pobytu, a 14 kněží bylo gestapem vyšetřováno a vesměs odsouzeno $k$ peněžité pokutě. $V$ souvislosti s tématem naší práce musíme připomenout postavu světce P. Engelmara Huberta Unzeitiga, provisora ve Zvonkové. Ten byl zatčen gestapem 1. řína 1940, nebot jak ve škole při vyučování, tak i z kazatelny odsuzoval vyhnání a genocidu Židů. Do koncentračního tábora $v$ Dachau přišel 3. června 1941, kde se dobrovolně přihlásil k ošetřování nemocných tyfem. Zemřel 2. března $1945 \mathrm{~s}$ přezdívkou „anděl z Dachau“.24

\section{Uprohlictví na konci vállky}

Konec druhé světové války znamenal pro velké množství lidí osvobození od jha nacismu, útlaku a nesvobody. Mnozí uprchlíci se zvolna navraceli do svých domovů. Byli ale i ti, kteří byli $\mathrm{v}$ důsledku přijetí principu kolektivní viny odsouzeni $\mathrm{k}$ uprchlictví či vyhnanství. Prezident Dr. Edvard Beneš vydal 19. 5. 1945 dekret o konfiskaci majetku Němců a Madarů, 2. srpna 1945 dekret o odejmutí státního občanství Němcům a Madarům, a tím začal naplňovat závěry jednání o odsunu třech milionů Němců z Československa. $Z$ území českobudějovické diecéze bylo vypraveno 110 transportů s celkem 127501 Němci do Německa. Je samozřejmé, že se svými farníky odcházeli do zahraničí i němečtí kněží českobudějovické diecéze. Do německých diecézí přešlo 71 kněží a do rakouských diecézí přešlo 16 kněží, tedy celkem 87 diecézních kněží německé národnosti opustilo v rámci odsunu českobudějovickou diecézi. Nejvíce diecézních kněží odešlo do diecéze Passau (28), Regensburg (20), Rottenburg (8) a Linz (8). Do S. Pölten odešlo 5 kněží, Vídně a Freiburgu 3 kněží, po dvou kněžích odešlo do Augsburgu, Bambergu, Mainzu a Mnichova a po jednom do Eichstättu, Fuldy, Limburgu a Würzburgu. Je otázkou, zda se snad některý kněz nestal obětí divokých odsunů. Dle bádání Emila Valaska založeného na svědomitém studiu dochovaných archivních pramenů tomu tak nebylo. ${ }^{25}$

V úředních listech českobudějovické diecéze je uveřejněno v souvislosti s odsunem Němců do Německa několik významných dokumentů. První pojednává o církevních obřadech v internačních a sběrných táborech a je vydán Zemským národním výborem v Praze. Pro internované osoby mohl kněz, $v$ jehož obvodu byl takovýto tábor umístěn, vykonávat jen nutné církevní obřady, a to tiché, bez promluv, „vzhledem $k$ povaze věci a $k$ danému prostředí ${ }^{26}$

23 Srov. Martin WEIS, Osudy katolické církve na jihu Čech v období Protektorátu Čechy a Morava, s. 63-70.

24 Tamtéž.

25 Srov. Catalogus saecularis et regularis cleri dioeceseos Bohemo-Budvicensis 1948 a personalia úředního listu diecéze z období 19451948. Podrobnější údaje je možné dohledat též v kněžské matrice. K odsunu německých kněží viz též velice zasvěcenou monografii Emil VALASEK, Der Kampf gegen die Priester im Sudetenland 1938 bis 1945. Ten ve své monografii uvádí podrobný soupis všech odsunutých německých kněží z českobudějovické diecéze včetně jejich osobních dat a stručného životopisu. Dle tohoto zdroje žádný německý kněz nebyl obětí lynčování a nezahynul v rámci tzv. divokého odsunu. Je však nutné připustit, že někteří němečtí kněží internovaní ve sběrných táborech před odsunem těžce nesli nucené práce, kterým byli podrobeni.

26 ACEB 1946, č. 2, s. 9 . 
Druhým význačným dokumentem je oběžník Zemského národního výboru v Praze ze dne 9. července 1946 pojednávající o odsunu německých kněží a zabezpečení far po nich, otištěný v celém rozsahu v úředním diecézním listu z července 1946. Tento oběžník sděloval, že předsednictvo vlády ve své 33 . schůzi konané dne 14 . května 1946 dovolilo vzíti odsunovaným německým kněžím s sebou místo dosud povoleného limitu $50 \mathrm{~kg}$ osobních zavazadel $100 \mathrm{~kg}$ i více, aby mohli $s$ sebou vzít své osobní př̀edměty, které potřebují $\mathrm{k}$ výkonu povolání, tj. kněžský oděv, mešní roucho, prádlo, breviár, misál atd., za předpokladu, že tyto věci jsou jejich osobním a ne farním majetkem a nejde o věci $z$ cenných kovü. ${ }^{27}$

Dne 28. srpna 1945 vydal papež Pius XII. poselství k 600. výročí narození sv. Jana Nepomuckého, které se stalo hlavní směrnicí pro poválečnou obnovu naší vlasti v duchovní oblasti. Papež Pius XII. nejdřive ve svém poselství připomenul smutné následky války a poté uvedl obraz sv. Jana Nepomuckého jako vzor pro duchovní obrodu válkou poznamenaného národa. Papež apeloval především na potřebu míru, který je vybudován na spravedlnosti a lásce. Varoval před výbuchy vášnivé nenávisti a pomstychtivosti, volal po pravé svobodě založené na ctnostech a úctě $k$ Bohu a varoval před bezuzdnou nevázaností a tyranií skrývající se pod rouškou nepravé svobody. $\mathrm{Na}$ toto papežské poselství navázal svým obsahem i první společný pastýřský list episkopátu republiky, který byl věnován současným nejnaléhavějším otázkám katolické církve v Československu. Ordináři ve svém pastýřském listu především upozorňovali na nebezpečný vzrůst novopohanského smýšlení a na krizi rodinného života. Apelovali na větší využívání nadpřirozených prostředků spásy, kladli důraz na křestanské školství, sociální reformy, větší péči o mládež a vybudování laického apoštolátu. Též upozorňovali slovy výše zmíněného poselství papeže Pia XII. na vztah k př́ślušníkům jiných národností, který měl být založen na spravedlnosti a lásce: „Jak se chovati $\mathrm{k}$ př́slušníkům jiné národnosti. Platí pro nás př́kaz sv. Otce $\mathrm{v}$ jeho listu k nám: ,At̉ nepřekračuje výkon spravedlnosti hranic práva a spravedlnosti. Není-liž opravdovým vítězstvím, jsme-li přemoženi spravedlností, jsme-li přemoženi láskou? At̉ s viníky nejsou trestáni také nevinní, a když se trestají viníci, at se to pak neděje nad správnou míru, aby při odsuzování viníků nebylo v trestu násilnictví, a to násilnictví odsouzení hodné, a at', rozsejí-li se všude semena zášti, neutrpí národ škody ve své nejvnitřnější vazbě. At u vás ve všem soukromém a veřejném jednání jako průvodkyně spravedlnosti se uplatňuje láska, která je vznešeným odznakem a neklamnou známkou křestanů.' Když jsme sami trpěli, bylo to pro nás čestné a je to pro nás slávou, když bychom se dopustili sami křivdy, bylo by to pro nás vinou před Bohem a skvrnou před lidmi, a zahraničí by nám to nezapomenulo. Ani stín ukrutnosti bývalých koncentračních táborů nás nesmí poskvrnit, protože historie má pronikavý zrak a $\mathrm{v}$ pozdějších letech by stavěla na pranýř každý přehmat tak, jako se dnes pranýŕuje krutost táborů v Dachau, Osvěnčimi a jiných.“. ${ }^{“ 8}$

Problematiku mnohdy zoufalých osudů německých kněží jako zajatců či uprchlíků dokumentuje i korespondence z biskupského archivu. První z nich je dopis P. Kroihera, bývalého senátora a duchovního $\mathrm{z}$ Ledenic, českobudějovické biskupské konsistoři, ve které popisuje nejenom těžké poničení pohraničního města České Velenice nálety, nýbrž i velmi tíživou situaci tamního kněze německé národnosti: „Ledenice dne 2. června 1945 Nejdůstojnější biskupská konsistoři! Píše mi jeden bývalý osadník $z$ Velenic o kostelu tamním: $V$ tomto hrozném rumišti zůstal kostel náš jako zázrakem takřka neporušen až na okna, která jsou vytlučena. Jediné okno s obrazem blahoslavené Anežky, tvořící součást hlavního oltáře, zůstalo úplně neporušeno. Též vnitřek kostela je úplně

27 Srov. ACEB 1946, č. 7b, 26. července 1946, s. 33.

28 ACEB 1945, č. 12, s. 39-41. 
zachován. Kolem kostela v parčíku jeden kráter za druhým, nejméně 20 děr. Domy kolem dokola jsou úplně pobořené, kostel a fara jako zázrakem zůstaly až na malé škody, které se nechají lehce zase napravit. Tamní pan farář, velmi hodný důstojný pán, mne prosil, abyste laskavě u biskupské konsistoře zapůsobil aby co nejdříve tam byl dosazen český duchovní. Doslovně mi prohlásil, že nechce kostel opustit a setrvá, až přijde český pan farář, kterému chce řádně a v pořádku vše předat, ale mám dojem, že se tam asi sám bojí, neb česky neumí a musí se modlit německy. Tolik doslova piše pan Květoň, bývalý předseda kostelního tamního spolku, jemuž jsem po vyhnání $\mathrm{z}$ Velenic opatřil místo $\mathrm{v}$ družstvu $\mathrm{v}$ Bechyni a jehož dům je $\mathrm{v}$ tak desolátním stavu, že se hned vrátiti nemůže. Podávaje tuto zprávu a tlumoče prosbu p. faráře poznamenávám, že píši současně známým Čechům, aby měli zatím trpělivost a nereptali a nedělali muži dobré vůle těžké srdce, neb nejsou časy jako před padesáti lety, kdy bylo kněží nadbytek..." ${ }^{\text {29 }}$

Další archivní dokument z listopadu 1945 nám líćí zoufalou situaci kněze českobudějovické diecéze, který byl jako sudetský Němec povolán do armády a po skončení války je v zajateckém táboře: „Brno - Slatina dne 21. 11. 1945 Důstojné biskupské konsistoři v Českých Budějovicích. Jsem knězem diecéze Česko - Budějovické, ordinován r. 1938, hlásím, že jsem se vrátil z ruského zajetí a že se nacházím v zajateckém táboře Brně - Slatina. Do roku 1940 jsem byl kaplanem ve Vimperku, z března až do října jsem byl kooperátorem v Reischachu u Alt Tötingu diecesis Passoviensis. Dne 7. října 1940 jsem se stal sanitárním vojákem v říšskoněmecké armádě, roku 1943 pomocníkem a vojenským kaplanem u vojenského faráře $\mathrm{v}$ lazaretě $1 / 606$. S tímto lazaretem a farářem jsem přišel do ruského zajetí dne 23. srpna 1944. Dne 1. září mne rudá armáda ze zajetí propustila jako nemocný. Přesto jsem nyní zadržen $\mathrm{v}$ zajateckém táboře $\mathrm{v}$ Brně - Slatina $\mathrm{z}$ mě neznámých důvodů. Zdravotnické a výživné poměry tohoto tábora jsou nedostatečné. Jelikož se jedná o pracovní tábor, jsem donucen často také vykonati práce nerovnající se s kněžským stavem. Tímto zadržením cítím se hlavně proto velice zatížen, poněvadž jsem nikdy nebyl členem NSDAP a jiných složek. Byl jsem následkem mého povolání vždy antifašistou. Důkazem zde řečeného nabízím svědectví bývalého představeného důst. preláta Dominik Brünner, děkana v. v. ve Vimperku a mého strýčka Dr. Václav Houschka. Co se týká dobu mého studia rok 1933-1938 uvádím důstojného pana rektora Karla Rebana. Proto prosím zdvořile, aby důst. konsistoř žádala u zemského velitelství vojenských zajateckých táborů v Brně o moje propuštění a návratu do domova. Josef Meisetschläger, kněz. ${ }^{\text {“30 }}$

Dalším dokumentem je přípis Děkanského úřadu v Táboře, ve kterém autor žádá o instrukce, co podniknout $\mathrm{v}$ záležitosti katolických kněží německých diecézí, kteří jsou v tamním zajateckém táboře coby vojáci zdravotní služby wehrmachtu. Za velice pozoruhodnou zmínku stojí, že místní důstojník Rudé armády chtěl tyto kněze propustit na svobodu, když se jich ujme nějaká oficiální církevní vrchnost: „Nejdůstojnější kapitolní konsistoři v Budějovicích. V Táboře jsou velké tábory zajatců, mezi nimi je 40 katol. kněží z Říše. Jsou to poddůstojníci u sanity a v kancelářích a 4 jako divisionpfarrer. Rádi by byli propuštěni do svých působišt. Naše vojenské velitelství nemá proti propuštění námitek, ale velitelství Rudé armády žádá souhlas některého nejdůstojnějšího biskupa, že by je vzal jako kněze. Vím, že takových př́padů budete míti více. Slíbil jsem, že učiním dotaz, jak by se dostali ze zajetí ven, odešli do svých působišt nebo mohli zatím zůstat volni na někte-

29 SOA Tř́eboň, fond BA, karton č. 958, signatura I - E - 4, spisovna 1903-1945, složka 1945, originál dopisu ze dne 2. 6. 1945, bez konceptu odpovědi.

30 SOA Třeboň, fond BA, karton číslo 996, složka perzekuce za války - dopisy v záležitosti německých duchovních po skončení války, originál signovaný, bez odpovědi na rubu žádosti. 
rých farách. Tábor 22. 5. 1945 Jaroslav Šebesta, děkan. “31 Na tuto žádost obdržel táborský děkan Jaroslav Šebesta značně strohou a zamítavou odpověd’ s tím, že o Němce se musí postarat německá diecéze: „Důstojnému děkanskému úřadu v Táboře. Na tamní dotaz z 22/5 1945 č. j. 415 odpovídáme: Zdejší ordinariát nemůže zmíněné kněze převzíti, poněvadž jsou německé národnosti. Všichni se musí obrátiti na své příslušné ordinariáty, respektive na některý německý ordinariát. “32

\section{Závěrem}

V této studii jsme přibližili problematiku uprchlictví z pohledu katolického duchovního českobudějovické diecéze, a to na základě archivních materiálů biskupského archivu. Druhá světová válka přinesla velké utrpení mnoha milionům lidí. Smrt na bojištích i v zázemí, neslýchané brutality koncentračních táborů, miliony uprchlíků, kteří ztratili své domovy a často i nejbližší. Studie dokumentuje na archivních materiálech, jak tuto skutečnost prožíval tehdejší duchovní katolické církve v regionu jižních Čech.

Na závěr této studie si dovolíme citovat slova, která tváří v tvář narůstající problematice uprchlictví považujeme za stále aktuální, byt zazněla před více než sedmi desetiletími: „Kéž by utrpení naší doby přineslo konec našemu utrpení navždy. Jen tehdy budou mít všechny ty nezměrné oběti, které musíme my, sudetští Němci, přinést a které přinesli v tak velké míre i Češi, nějaký význam. Jen tehdy posloužily nejvyššímu ideálu lidstva - trvalému a čestnému míru. ${ }^{\text {“33 }}$

1 Tamtéž, originál signovaný, na rubu je koncept odpovědi biskupské konsistoře.

32 Tamtéž, koncept odpovědi biskupské konsistoře na rubu předchozí žádosti.

33 Poslední vystoupení Hanse Krebse, německého poslance odsouzeného v Praze k trestu smrti 15. 1. 1947. Milan SLÁDEK, Němci v Čechách, s. 151-153. 


\section{Druhá světová válka a problematika uprchlictví se zaměřením na českobudějovickou diecézi ve světle archivních materiálů biskupského archivu}

\section{Abstrakt}

Druhá světová válka přinesla nezměrné utrpení mnoha milionům lidí. Nelze ani spočítat, kolik lidí muselo v důsledku válečných operací či z rozhodnutí státníků opustit své domovy a byli bud' násilně deportováni či sami utekli do exilu. V této studii připomínáme problematiku uprchlictví spojenou s tímto tragickým úsekem lidských dějin ze specifického úhlu pohledu, a to uprchlictví jako součást dějin českobudějovické diecéze let 1938 až 1947 ve světle archivních materiálů biskupského archivu. Na autentických dokumentech si přibližujeme, jak otázku uprchlictví vnímal a často i sám jako uprchlík prožíval tehdejší katolický duchovní českobudějovické diecéze.

Klíčová slova: církevní dějiny, nacistický režim, uprchlictví, druhá světová válka, českobudějovická diecéze

\section{Kontakt na autora}

prof. ThLic. PaedDr. Martin Weis, Th.D.

Jihočeská univerzita v Českých Budějovicích

Teologická fakulta, Katedra teologických věd

Kněžská 8, 37001 České Budějovice

weis@tf.jcu.cz 